\title{
ARCHITECTURE AND EMPIRE AT LATE PREHISPANIC TARAPACÁ VIEJO, NORTHERN CHILE
}

\author{
ARQUITECTURA E IMPERIO EN TARAPACÁ VIEJO, UN SITIO PREHISPÁNICO \\ TARDÍO EN EL NORTE DE CHILE
}

\author{
Colleen Zori ${ }^{1}$ and Simón Urbina A..$^{2,3}$
}

\begin{abstract}
Imperial conquest and subsequent strategies of integration can be detected in changes to regional infrastructure, such as road systems and the architectural layout and construction techniques of provincial settlements. Located in the Tarapacá Valley of northern Chile, the site of Tarapacá Viejo underwent significant architectural remodeling when the valley was incorporated into the Inka empire in the XV century AD. This article examines (1) how Tarapacá Viejo fit into the overall network of Inka or Inka-influenced sites in northern Chile; (2) how the construction techniques and architectural layout were transformed upon conquest of the valley by the Inka; and (3) what changes and continuities characterized the Early Colonial period (AD 1,532-1,700) occupation of the site. These data provide insight into the strategies of provincial incorporation employed by the Inka in this arid and sparsely populated region and how they were shaped by pre-existing settlement patterns, infrastructure, and economic conditions.
\end{abstract}

Key words: Andes, Inka, imperialism, architecture, Tarapacá Viejo, Colonial period.

Las conquistas imperiales y las subsecuentes estrategias de integración pueden ser detectadas arqueológicamente a partir de los cambios en la infraestructura regional, como los sistemas de caminos, el urbanismo y las técnicas constructivas en los asentamientos provinciales. Localizado en el valle de Tarapacá, actual norte de Chile, el sitio Tarapacá Viejo sufrió remodelaciones arquitectónicas significativas mientras el valle era incorporado al Tawantinsuyo en el siglo XV d.C. Este artículo examina (1) cómo Tarapacá Viejo fue inserto, y articulado, dentro de la red de instalaciones Inka y asentamientos bajo su influencia en el norte de Chile, (2) cómo las técnicas de edificación y el diseño arquitectónico fueron transformados en el valle bajo la presencia Inka y, finalmente, (3) qué cambió o se mantuvo en la ocupación del asentamiento durante el período Colonial Temprano (1.5321.700 d.C.). La información entrega nociones precisas sobre las estrategias de incorporación provincial utilizadas por el Inka en esta árida y dispersamente habitada región, y cómo dichas estrategias fueron modeladas por los patrones de asentamiento, infraestructura y condiciones económicas previas a la expansión del Tawantinsuyo.

Palabras claves: Andes, Inka, imperialismo, arquitectura, Tarapacá Viejo, periodo Colonial.

Changes in regional infrastructure, settlement layout, and architectural styles are potential indicators of imperial expansion and subsequent provincial integration. Such changes can provide important insights into the nature of the relationship between local populations and representatives of the empire, and how imperial strategies of incorporation were shaped by pre-existing settlement patterns, infrastructure, and political and economic conditions.

This paper addresses Inka imperialism in northern Chile, a region known for its rich mineral resources, by investigating the choice of Tarapacá Viejo as an imperial administrative node (Figures 1,2). We first examine Tarapacá Viejo in light of the changes in settlement distributions, the road network connecting key centers, site layouts, and construction techniques that accompanied the incorporation of northern Chile into the Inka empire during the Late Horizon (AD 1,450-1,532). The transformations of its layout and construction techniques subsequent to conquest demonstrate the symbolic hegemony of the imperial power, but the strategies of integration also included incorporation of local architectural traditions, suggesting that the empire took a diplomatic approach to interactions with residents of this center. A contrast in imperial styles is then drawn by comparing Inka Tarapacá Viejo with the archaeological evidence for changes that took place after the incorporation of the region into the Spanish empire during the Early Colonial period (AD 1,532-1,700).

\footnotetext{
1 Cotsen Institute of Archaeology, University of California, Los Angeles, 308 Charles E. Young Drive North, A201 Fowler Building, Box 951510, Los Angeles, CA 90095-1510, USA. colleen.zori@ucla.edu

2 Instituto de Historia y Ciencias Sociales, Universidad Austral de Chile, Casilla 787, Valdivia, Chile. simon.urbina@uach.cl

3 Programa de Doctorado en Historia, Universidad de Chile, Santiago, Chile.
} 


\section{Situating Tarapacá Viejo in the Inka Road Network}

A primary factor influencing the selection of Tarapacá Viejo as an administrative center were the ecologically cross-cutting trade relationships maintained by its inhabitants in the period preceding the arrival of the Inka. A growing body of data suggests that the Late Intermediate period (AD 1,000-1,450) in northern Chile was characterized by elevated levels of interregional trade between the coast, transverse valleys, and highlands, most probably via camelid caravans (Briones et al. 2005; Uribe and Urbina 2010; see also Dillehay and Núñez 1988). Excavations at Tarapacá Viejo yielded a range of staple and prestige goods from the coast and highlands (Zori 2011). Comparing surface ceramic collections across a number of prehistoric sites in northern Chile indicates that the inhabitants of Tarapacá Viejo had access to a comparatively wider range of pottery styles than other settlements, suggesting that the site was an important axis on trade routes during the pre-Inka period (Uribe et al. 2007, Tabla 3:159). Analysis of faunal remains from Tarapacá Viejo indicates that a large percentage -almost 30\%- of the camelid assemblage is constituted by juvenile individuals (Zori 2011:518-519). Elsewhere in the Andes, this has been interpreted as evidence that camelid breeding and the maintenance of a herd were undertaken locally by site residents (deFrance 1996; Shimada and Shimada 1985), suggesting that the pre-Inka inhabitants of Tarapacá Viejo were wellequipped to engage in extensive interregional trade with the coast, highlands, and the other valleys of northern Chile.

As the Inka formalized their road system through the region, Tarapacá Viejo remained a central node for administrators, military troops, messengers, and camelid caravans moving between the coast, valleys, precordillera and altiplano (Figure 1). No fewer than four important Inka routes converge in or near Tarapacá Viejo. The first is a roughly northsouth trunk route known as the Camino Real de la Costa or the Camino Real de los Llanos. This road follows the Pacific coastline in extreme northern Chile before angling southeast across the Pampa de Tamarugal to intersect the Tarapacá Valley at Tarapacá Viejo (Advis 2008:148-168; Bollaert 1851; Briones et al. 2005; discussion in Zori 2011:345-346). To the south, this route skirts the eastern edge of the
Pampa de Tamarugal, passing through Pica and the Guatacondo Valley before arriving at the Rio Loa. A second route connects Tarapacá Viejo with the upper transverse valleys of far-northern Chile and southern Peru. Running south-southwest between the Andes and Huaylillas ranges, this road originates in the highlands near Tacna and passes through numerous habitation sites and tampus, including Zapahuira (see below), before joining the other north-south route at Tarapacá Viejo.

Two transverse routes link Tarapacá Viejo to the Andean highlands to the east. One runs through Tarapacá Viejo, forming the main east-west axis of the town (Figure 2), and then travels up the valley before ascending a slope east of Pachica. This route passes through the tатри of Correlones and then the tampu/administrative center of Inkaguano (see below; Berenguer et al. 2011; Urbina 2009; Zori 2011). It then continues on to Inka settlements in the territory occupied by the Carangas and Soras ethnic groups, such as Turco and Oruro. A second transverse route angles to the south, passing through the upper Collacagua valley before travelling through the region between the Bolivian salt pans of Coipasa and Uyuni and into the lands held by the Quillacas and Lípez ethnic groups.

Although it has not been documented archaeologically, the transverse branch of the Inka road through the Tarapacá Valley probably continued westward across the Pampa de Tamarugal, connecting the valley to the coast near modern-day Iquique (Berenguer 2009; Hidalgo 2009 [O'Brien 1765]). Ethnohistoric documents attest to Inka exploitation of the Huantajaya silver mines (Cobo 1979 [1653]; Pizarro 1986 [1571]; Zori and Tropper 2010), and suggest that the labor needed to extract these ores was drawn from the surrounding valleys (Pizarro 1986 [1571]:189-192; Trelles 1991:175-176). Analyses of metallurgical materials from the Tarapacá Valley indicate that Tarapacá Viejo was a key location for refining the silver-bearing ores that were subsequently appropriated by the Inka (Zori and Tropper 2010, 2013). The role in silver mining and subsequent refining hypothesized for the inhabitants of the Tarapacá Valley increases the likelihood of physical connections between the valley and the coast, and also helps to explain the investment of Inka efforts at the site of Tarapacá Viejo. Administrative activities at the site carried out on behalf of the empire would have included the organization of mining labor, the transport and subsequent refining of the extracted 


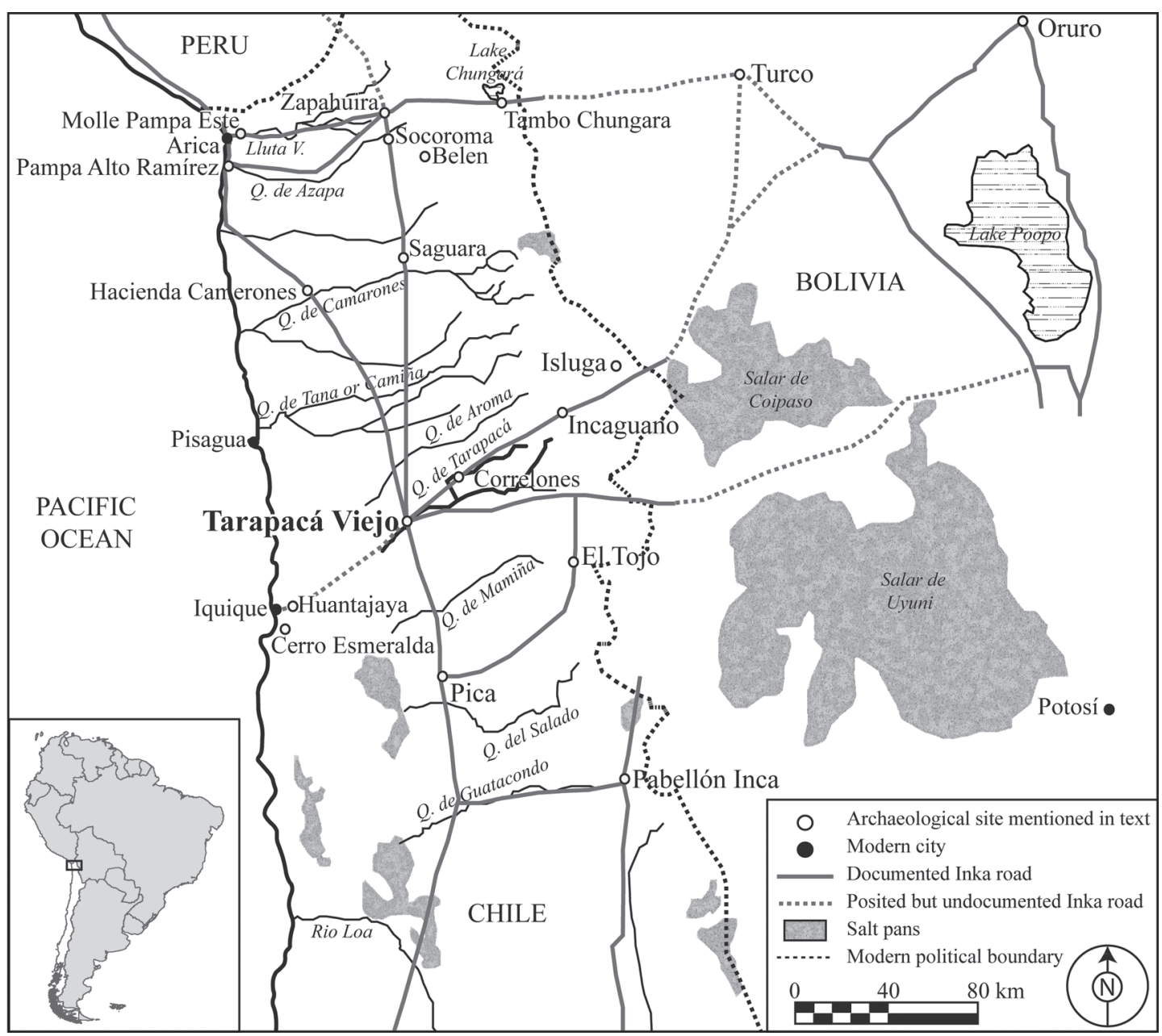

Figure 1. Northern Chile, showing location of Tarapacá Viejo and the Tarapacá Valley, as well as Inka road network and administrative nodes (based on Berenguer 2009).

Ubicación de Tarapacá Viejo, valle de Tarapacá, red vial e instalaciones administrativas incaicas en el norte de Chile (basado en Berenguer 2009).

ores, the collection of the purified silver, and the provisioning of food, fuel, and other resources to individuals engaged in metallurgical labor for the empire (Zori 2011).

In comparison with other Inka and Inkainfluenced sites in northern Chile, such as Molle Pampa Este, Pampa Alto Ramírez, Saguara, Hacienda Camerones, Zapahuira, and Inkaguano (Figure 1), Tarapacá Viejo is uncommonly well-connected with the highlands, other transverse valleys, and the coast. The sites of Molle Pampa Este and Inkaguano are each traversed by a single east-west route, and Saguara and Hacienda Camerones are similarly bisected by the north-south routes running through the Pampa de Tamarugal and through the precordillera, respectively. On the coast, Pampa Alto Ramírez is located on the north-south Camino Real de la Costa and is the endpoint of the east-west transverse road up the Azapa Valley. Zapahuira is likewise situated at the crossing of the same eastwest transverse road and the north-south route through the precordillera. By contrast, Tarapacá Viejo is located at the intersection of the northsouth roads through both the Pampa de Tamarugal and the precordillera, two east-west routes into the Bolivian altiplano, and a presumed road connecting the Tarapacá Valley with the coast (Figure 1). Its central location in the empire's administrative network attests to the integral role of the site in Inka governance of the region. 


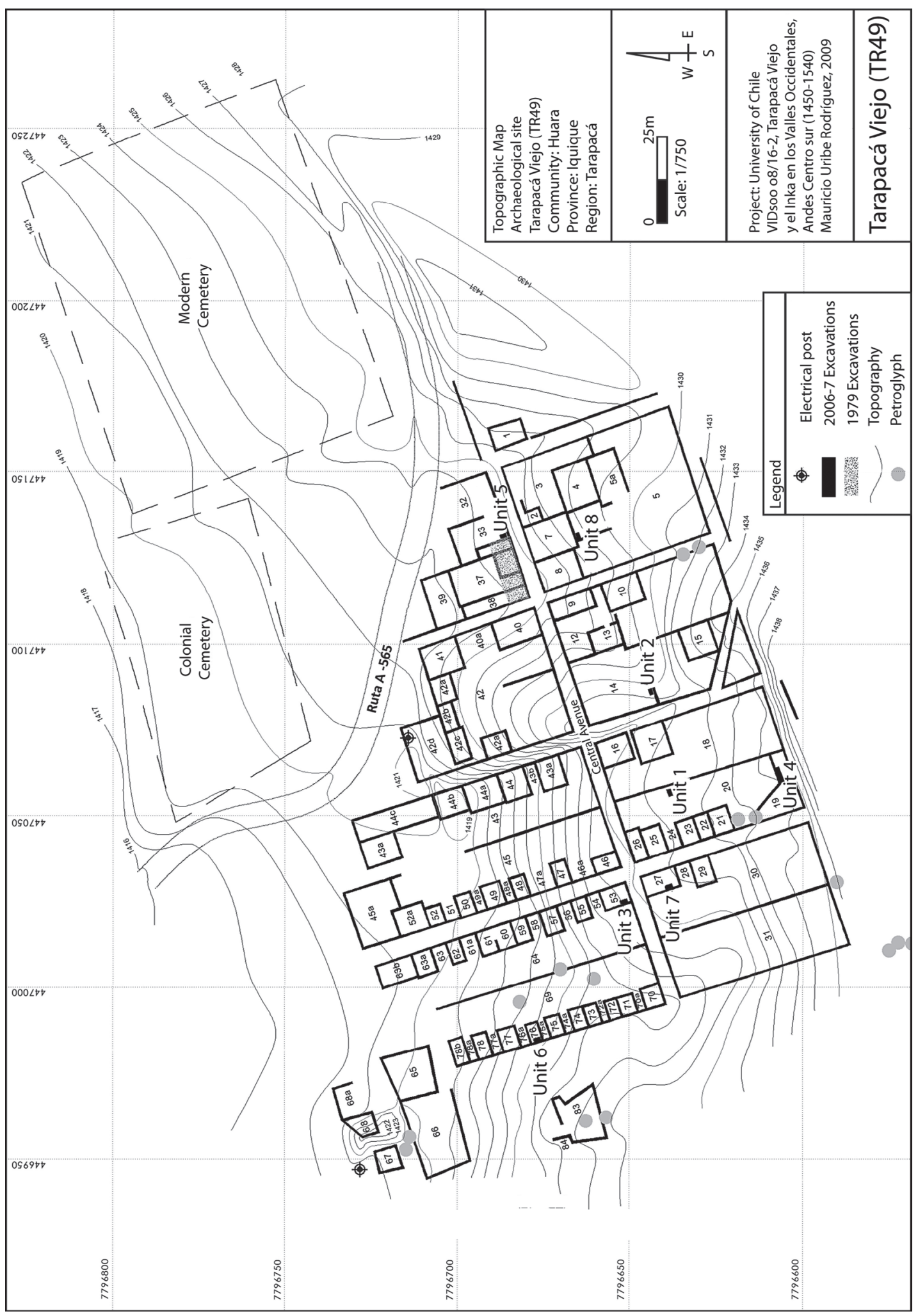

Figure 2. Architectural map of Tarapacá Viejo (modified from Uribe and Urbina 2010).

Mapa arquitectónico de Tarapacá Viejo (modificado de Uribe and Urbina 2010). 


\section{Nodes of Inka Interaction in Northern Chile}

The Inka incorporated northern Chile's varied geographic and environmental zones, including the coast, the transverse valleys (up to approximately 2,000 masl), the precordillera (between 2,000-3,000 masl), and the altiplano (above 3,000 masl). Late prehistoric sites in northern Chile can be divided into (1) local settlements that may contain some imperial-style artifacts but that have no evidence of Inka architectural influence; (2) pre-existing sites whose architecture is primarily local but that have intrusive imperial architecture; and (3) sites founded and built by the Inka (Niemeyer and Schiappacasse 1988; Adán 1999; Santoro et al. 2010; Urbina 2009; Uribe and Adán 2004). Although we recognize that direct and indirect exchange of Inka goods was an important diplomatic strategy employed by the empire, we leave aside the first type of site to focus on the distribution of the other two site types and how their architectural layouts and construction methods were altered by the Inka. Through this analysis, we develop a schema for understanding the degree of imperial architectural intervention in particular environmental zones, as well as a suite of architectural forms and building techniques characteristic of Inka and Inka-influenced sites in northern Chile (Table 1). This allows an evaluation of Tarapacá Viejo's role in the network of imperial control over the region, and provides comparative data for assessing the degree to which architectural changes there reflect the influence of the Inka.

\section{The coast}

Inka access to coastal resources -such as guano, dried fish and other marine products, and the modest agricultural potential of the mid- to lower valleys- appears to have been mediated through prestige goods exchange between local and imperial elites, as suggested by the incorporation of Inka goods in many tombs at local cemeteries (Santoro et al. 2004; 2010). Nonetheless, existing sites at or near the coast of far northern Chile also saw some degree of architectural intervention by the Inka. Stone platforms at the site of Molle Pampa Este (Santoro et al. 2004; 2010), built with roughly cut stones and an ashy mortar, are thought to have been foundations for long, rectangular Inka structures called kallankas (Hyslop 1990:18; Gasparini and Margolies 1980). Archaeologists additionally

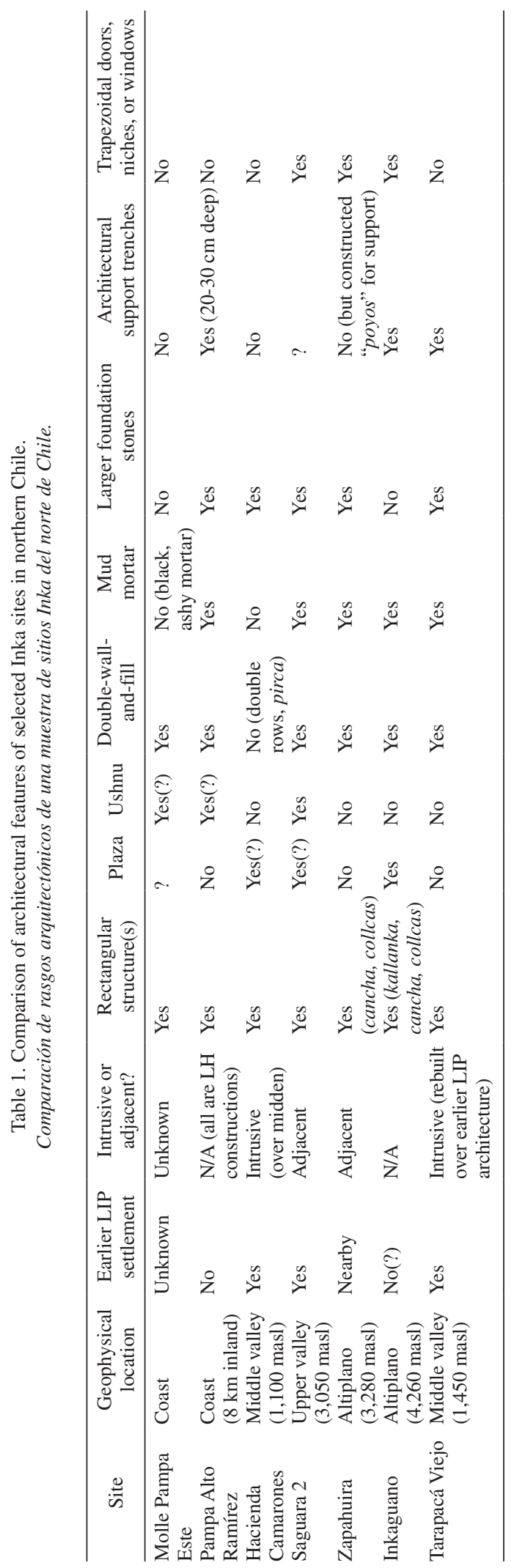


identified what may have been an ushnu, a stepped stone or earthen structure found in Inka plazas and representative of the power and authority of the state (Hyslop 1990). Ethnohistoric sources recount the diverse roles of ushnu in provincial administration: that they served as thrones, places of ritual offerings, tools for solar observation, a place for administering justice, and a stand from which to view troops and issue commands.

At the coastal site of Pampa Alto Ramírez, an intrusive rectangular stone building has been interpreted as an Inka domestic structure, while a small, raised platform to the east may have been an ushnu (Piazza 1981; Santoro and Muñoz 1981). The stone edifice was constructed using double-walland-fill architecture with unworked stones set into mud mortar, and the lower courses of the wall were set into trenches cut approximately $20-30 \mathrm{~cm}$ into the ground (Figure 3; Piazza 1981:187; Santoro and Muñoz 1981:151). Ethnohistoric documents and archaeological evidence confirm that use of architectural support trenches was a technique employed by the Inka. Cieza de León recounts the use of foundational trenches in the construction of monumental state architecture, such as the fortress/ temple of Sacsayhuaman: "[f]our thousand of them quarried and cut the stones; six thousand hauled them with great cables of leather and hemp; the others dug the ditch and laid the foundations, while still others cut poles and beams for the timbers" (Cieza de León 1959 [1553]; Ch. 46, emphasis ours). A second example is the construction of the site of Incahuasi (Cieza de León 1959 [1553], Ch. 117): "after they had laid open the hill with their picks and tools, they covered the cavities that they had dug with big slabs and stones, and with these foundations the structure was strong". Archaeologically, support trenches have been identified in other Inka buildings in northern Chile, including the kallanka at Turi (Gallardo et al. 1995).

\section{Transverse valleys and precordillera}

In the middle and upper transverse valleys and into the precordillera of northern Chile, the Inka did not establish new settlements, but rather, oversaw the construction of imperial structures within or adjacent to pre-existing local sites. Hacienda Camarones, located in the mid-Camarones Valley at approximately 1,100 masl, had a Late Intermediate period occupation comprised of agglutinated circular structures of stones piled together without mortar or discernible courses (Niemeyer and Schiappacasse 1988). A rectilinear open space defined by a low wall and a smaller rectangular structure were intrusive into the settlement, as evidenced by their construction over earlier midden deposits. The Inka structures were built using double walls with neither fill nor

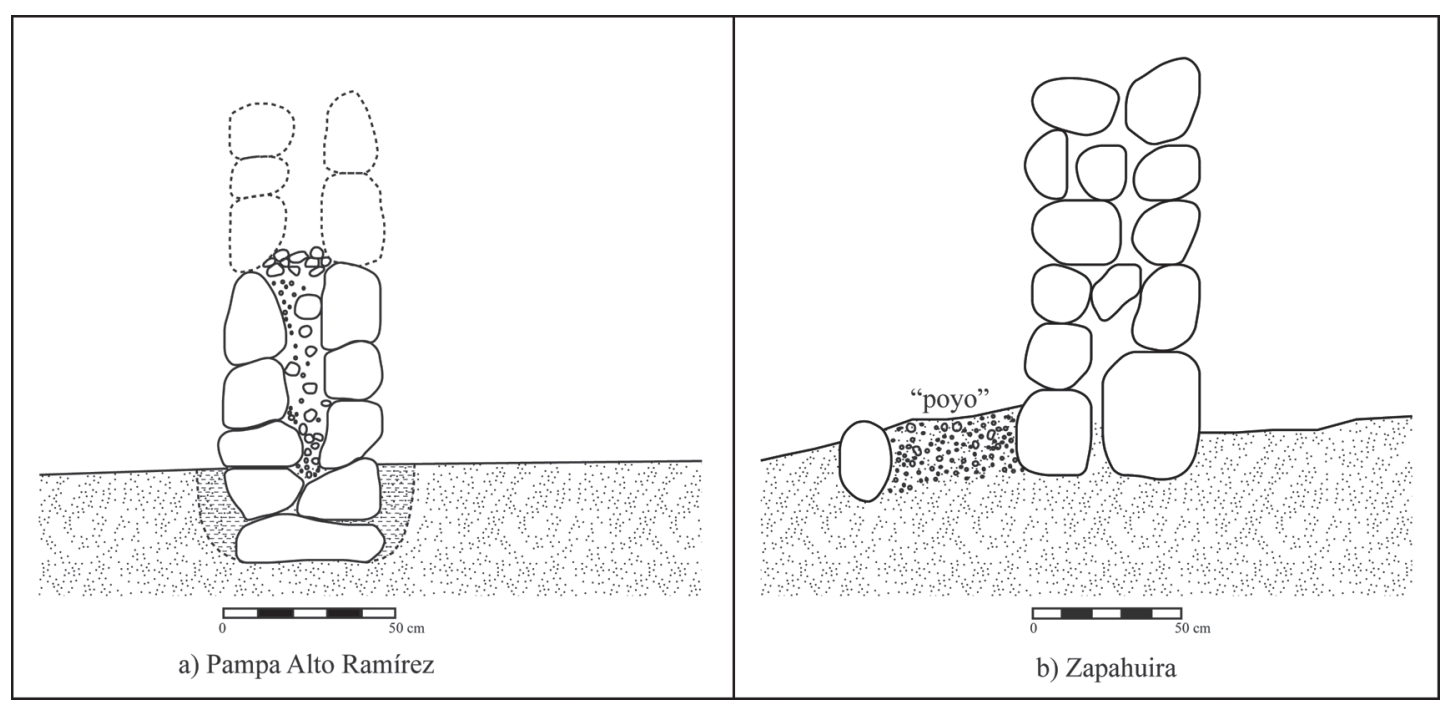

Figure 3. (a) Profile view of wall construction at Pampa Alto Ramírez; (b) profile of wall construction at Zapahuira (redrawn from Piazza 1981:Lamina 16, p. 205, and Muñoz et al. 1987:Lamina 4, p. 89).

(a) Vista de perfil muro construido en Pampa Alto Ramírez; (b) perfil de un muro construido en Zapahuira (redibujado de Piazza 1981: Lámina 16, p. 205 y Muñoz et al. 1987: Lámina 4, p. 89). 
mortar, and are notable for their large foundation stones (Niemeyer and Schiappacasse 1988:129).

The site of Saguara, located at 3,050 masl in a tributary of the Camarones River, contains an imperial civic-ceremonial sector with an ushnu, a 2 m-high platform with a large, rectangular base $(23.5 \times 11.2$ $\mathrm{m})$ and five stone-built stairs (Schiappacasse and Niemeyer 2002). Twenty-nine rectangular structures with double-wall-and-fill architecture using mud mortar make up the remainder of the Inka sector. Although they do not mention support trenches, the investigators note that the foundation stones of the walls were larger than those of the upper courses and were securely embedded in the ground (Schiappacasse and Niemeyer 2002:59). A trapezoidal niche, a quintessential marker of Inka architectural style, was identified in one enclosure. Local inhabitants lived downstream in circular structures of stones piled together without mortar or distinct courses.

\section{The Altiplano}

Along the imperial road in the altiplano of far northern Chile, the Inka founded numerous sites that functioned as way-stations, or tampu, supporting military and administrative traffic. Most were established in areas uninhabited during the preceding Late Intermediate period, although associated dwellings in local styles suggest that people from surrounding communities who were responsible for maintaining the tатри lived there during the Late Horizon.

The tampu of Zapahuira, located at 3,280 masl at the intersection of the branches of the Inka roads traversing the Lluta and Azapa valleys, comprises (1) two canchas with perimeter walls enclosing rectangular rooms opening onto an interior patio; (2) two lines of rectangular storage structures with prepared gravel floors and stone-lined ventilation ducts; and (3) a number of circular structures interpreted as dwellings and corrals (Figure 4; Berenguer 2009; Muñoz et al. 1987; Santoro et al. 2010). Canchas, rectangular structures arrayed around an open space or patio and enclosed by an exterior rectangular compound wall, were the principle Inka residential layout (Gasparini and Margolies 1980; Hyslop 1984, 1990). The tampu structures at Zapahuira were built using double-wall-and-fill construction employing a mud mortar (Santoro et al. 2010:57). Although unworked, the stones were chosen with care, positioned to present the flattest external surface, and set into relatively uniform horizontal rows. The foundation stones of the walls were larger than those used in the upper courses. No architectural support trenches were identified at Zapahuira, but the walls were buttressed by what are known as a "poyos": gravel held in place by low retaining walls running parallel to the exterior walls of the storage structures and canchas (Figure 3; Muñoz et al. 1987:89).

Located at 4,260 masl in the altiplano east of the Tarapacá Valley, the site of Inkaguano is thought to have played an important role in mediating long-standing conflict over land and resources between groups in the altiplano and the transverse valleys (Berenguer 2009; Berenguer et al. 2011; Sanhueza 2008; Urbina 2009). Situated on the transverse road connecting Tarapacá Viejo and the Bolivian altiplano, the tатри centers on a rectangular plaza that has been artificially leveled (Figure 5). Surrounding this plaza are a kallanka, a cancha of five rooms opening onto a central patio, and a number of rectangular storage structures (Berenguer 2009; Urbina 2009). The kallanka and cancha have gabled roofs, as well as cylindrical bosses used in affixing them, typical of the imperial Inka architectural style (Figure 5 inset; Urbina 2009). The walls of the Inka structures are double-wall-and-fill architecture with lightly worked stones set in uniform courses, covered on the internal and external faces by a fine mud plaster. Many of the site's doors and windows are trapezoidal in shape. Surrounding the civic-ceremonial core, approximately 30 circular and rectangular enclosures indicate that site housed local residents, as well as possibly colonists resettled there by the empire (Urbina 2009).

Although some variability in site location, architectural layout, and construction methods derives from historical circumstances and interaction with particular local populations, the Inka systematically integrated the coast, valleys, precordillera, and highlands of northern Chile into a predictable pattern of nodes linked by the imperial road system. Tarapacá Viejo, located at 1,350 masl, fits into the pattern of mid -to upper- valley Inka administrative sites established at places with important Late Intermediate period occupations.

\section{Late Prehispanic Architectural Changes at Tarapacá Viejo}

The degree of architectural intervention at Tarapacá Viejo is greater than at most other Inka 


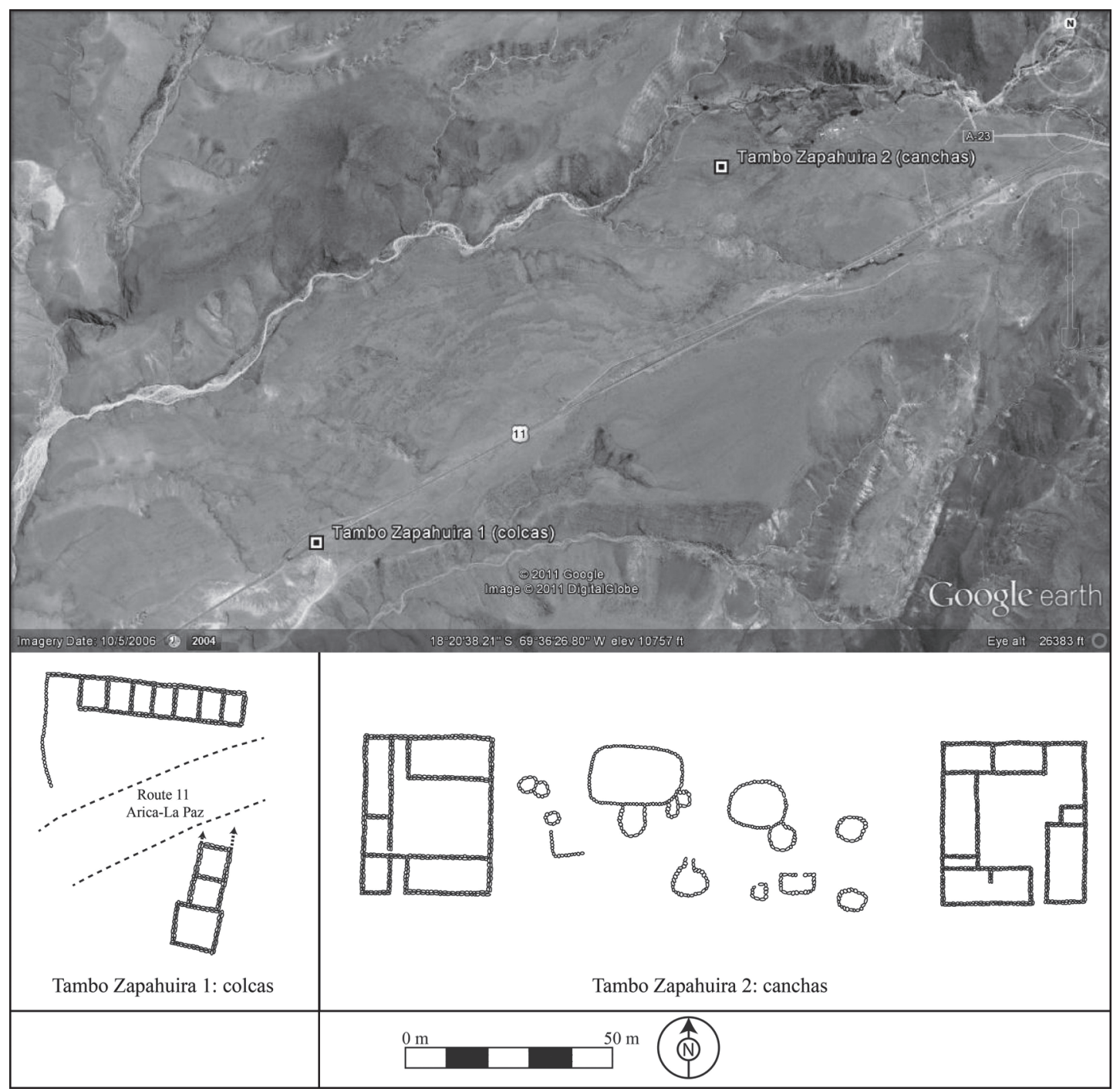

Figure 4. Architectural layout of Inka structures at Zapahuira (redrawn from Muñoz et al. 1987: Lamina 4, p. 89, image from Google Earth).

Planta arquitectónica de estructuras Inka en Zapahuira (redibujo de Muñoz et al. 1987: Lámina 4, p. 89; imagen de Google Earth).

sites in northern Chile, and reflects the logistical and economic importance of this node within the administrative network integrating the region. The data presented here derive from numerous sources: (1) visual inspection, systematic recording of $100 \%$ of the architectural features, and total station mapping of the extant surface architecture (Adán and Urbina 2005; Uribe and Urbina 2010; Uribe et al. 2012); (2) systematic surface collection of ceramics (Uribe et al. 2007); (3) the excavation of a sample of $10 \%$ of the rooms at Tarapacá Viejo, comprising seven $1 \times 2 \mathrm{~m}$ test units and one $1 \times 4.5$ $\mathrm{m}$ trench in a variety of the different architectural contexts at the site (Figure 2; Zori 2011); and (4) six radiocarbon dates obtained from a range of these excavation contexts (Table 2 and Figure 6). We begin by outlining the style of construction used at Tarapacá Viejo in the pre-Inka period, and then discuss the site layout and changes in building style and technique under Inka rule. 


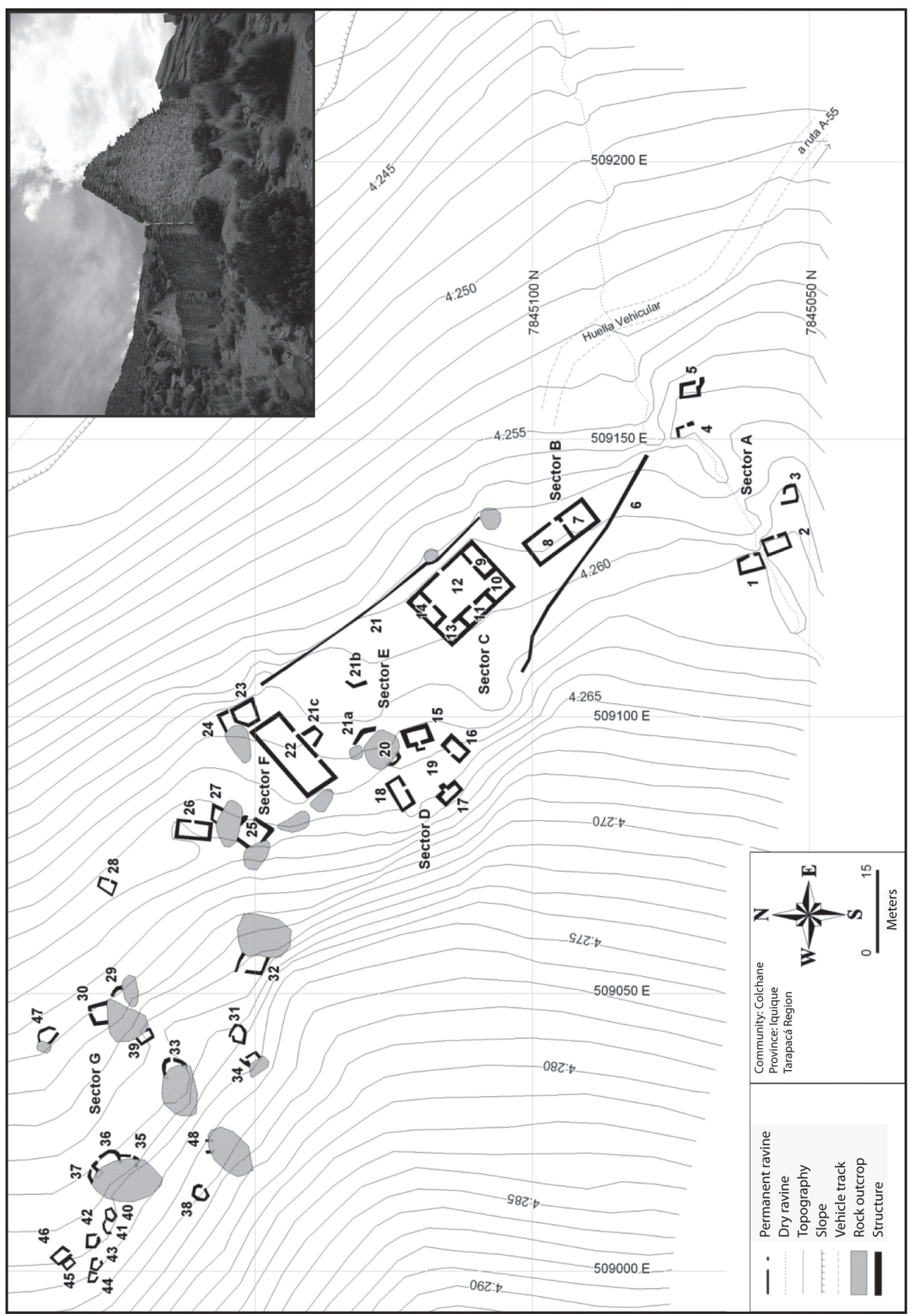

Figure 5. Architectural layout of Inka portion of Inkaguano (modified from Berenguer et al. 2011: Figure 7). Inset: gabled structure at Inkaguano with cylindrical bosses.

Planta arquitectónica del sector Inka en Inkaguano (modificado de Berenguer et al. 2011: Figura 7). Inserto: estructura a dos aguas en Inkaguano con salientes cilíndricos. 
Table 2. Radiocarbon dates from Tarapacá Viejo excavation contexts (from Uribe et al 2009; Uribe and Urbina 2010; Zori 2011; calibrated using OxCal 4.1, Bronk Ramsey 2009). Fechados radiocarbónicos ${ }^{14} \mathrm{C}$ de contextos excavados en Tarapacá Viejo (en Uribe et al. 2009; Uribe and Urbina 2010; Zori 2011; calibrados mediante OxCal 4.1, Bronk Ramsey 2009).

\begin{tabular}{|c|c|c|c|c|}
\hline Sample & Facility and Internal Sample Number & Material and Context & $\begin{array}{l}{ }^{14} \mathrm{c} \mathrm{Age} \\
(\mathrm{BP})\end{array}$ & $\begin{array}{l}2 \sigma \text { Calibrated } \\
{ }^{14} \mathrm{C} \text { Age }\end{array}$ \\
\hline TR49-A2-L15 & $\begin{array}{l}\text { University of California, Irvine AMS } \\
\text { Laboratory; } 58816\end{array}$ & Corn cob; from beneath floor & $495 \pm 15$ & AD $1,413-1,440$ \\
\hline TR49-A3-L3 & $\begin{array}{l}\text { Universidad de Chile; Beta } 269050 \\
\text { (courtesy of M. Uribe) }\end{array}$ & $\begin{array}{l}\text { Grain of wheat; post-occupation trash } \\
\text { layer }\end{array}$ & $350 \pm 40$ & $\mathrm{AD} 1,450-1,650$ \\
\hline TR49-A3-L14C & $\begin{array}{l}\text { Universidad de Chile; Beta } 269052 \\
\text { (courtesy of M. Uribe) }\end{array}$ & $\begin{array}{l}\text { Kernel of corn; pit excavated through } \\
\text { Late Intermediate Period floor }\end{array}$ & $350 \pm 40$ & $\mathrm{AD} 1,460-1,660$ \\
\hline TR49-A5-L14-CS1 & $\begin{array}{l}\text { Universidad de Chile; Beta- } 294704 \\
\text { (courtesy of M. Uribe) }\end{array}$ & $\begin{array}{l}\text { Charcoal; layer directly above Late } \\
\text { Intermediate Period floor }\end{array}$ & $370 \pm 30$ & AD $1,450-1,540$ \\
\hline TR49-A5-L16-CS1 & $\begin{array}{l}\text { NSF - Arizona Accelerator Mass } \\
\text { Spectrometry (AMS) Laboratory; } \\
\text { AA82247 }\end{array}$ & $\begin{array}{l}\text { Guinea pig fur; dedicatory offering from } \\
\text { beneath Late Intermediate Period floor }\end{array}$ & $662 \pm 38$ & AD $1,273-1,396$ \\
\hline TR49-A7-L17-CS1 & $\begin{array}{l}\text { NSF - Arizona Accelerator Mass } \\
\text { Spectrometry (AMS) Laboratory; } \\
\text { AA82248 }\end{array}$ & $\begin{array}{l}\text { Corn cob; from beneath floor lipping up } \\
\text { on wall in Area } 7\end{array}$ & $618 \pm 39$ & AD $1,289-1,405$ \\
\hline
\end{tabular}

\section{Local style construction of the Late Intermediate Period}

Late Intermediate Period (AD 1,000-1,450) sites in the Tarapacá Valley were inhabited by people sharing in the Pica-Tarapacá Complex, a suite of material objects, iconography, and cultural practices shared by inhabitants of the coast and valley-oases of northern Chile between A.D. 900-1,450 (L. Núñez 1979, 1984; Cúneo Vidal 1977; Uribe 2006; Uribe et al. 2007).The local architectural tradition in the Tarapacá Valley during this period is defined by agglomerated settlements with little evidence of an overarching settlement plan (Figure 7; see also P. Núñez 1983, 1984; Zori 2011). Most of the larger villages are located on the southern flank of Tarapacá drainage, on flat or gently sloping terrain. The structures in these villages are rectilinear, often comprising square or rectangular compounds with internal architectural divisions. Walls -usually a single line of stones- were erected using stone and anhydrite (caliche), and sometimes incorporated mud mortar and stucco. The buildings were often roofed, supported by wooden posts (Prosopis sp.) embedded in the exterior walls. Storage pits are frequently found dug into the sterile substratum.

Little is known about the earliest layout of Tarapacá Viejo, as the remaining surface architecture dates to the Inka (AD 1,450-1,532) and Early Colonial (AD 1,532-1,700) periods. Nonetheless, excavations at Tarapacá Viejo encountered subsurface remnants of architectural constructions dating to the period preceding Inka conquest, the Late Intermediate period. At this time, local groups using ceramics of the Pica-Tarapacá Complex (Pica-Charcollo, Pica-Gris Alisado, Pica Chiza; see Uribe et al. 2007, Table 2:156) began to lay down prepared mud floors just atop the rock of the hillside. The temporal affiliation of these floors is supported by the fact that the floor layers and the deposits immediately beneath contain only ceramics of Pica-Tarapacá Complex styles, without a single sherd deriving from the altiplano traditions that became common just prior to and under Inka rule (Uribe et al. 2007). Calibrated radiocarbon dates for the floors in Unit 5 and Unit 7 were 1,273-1,386 cal. AD (calibrated at $2 \sigma$ using OxCal 4.1, Bronk Ramsey 2009) and $1,289-1,405$ cal. AD (calibrated at $2 \sigma$ using OxCal 4.1, Bronk Ramsey 2009) respectively (Figure 2 for locations of excavation units and Figure 6 for the stratigraphic locations of the radiocarbon dated floors). Other floors thought to date to the Late Intermediate period were also found in Units 1, 2, 3, 4 , and 6 (Table 2). These results are congruent with Phase I of Tarapacá Viejo's occupation as defined by Patricio Núñez, who conducted excavations in the northeastern sector of the site in the late 1970s (P. Núñez 1984:56, 61).

One wall revealed during test excavations can be ascribed with certainty to the Late Intermediate 


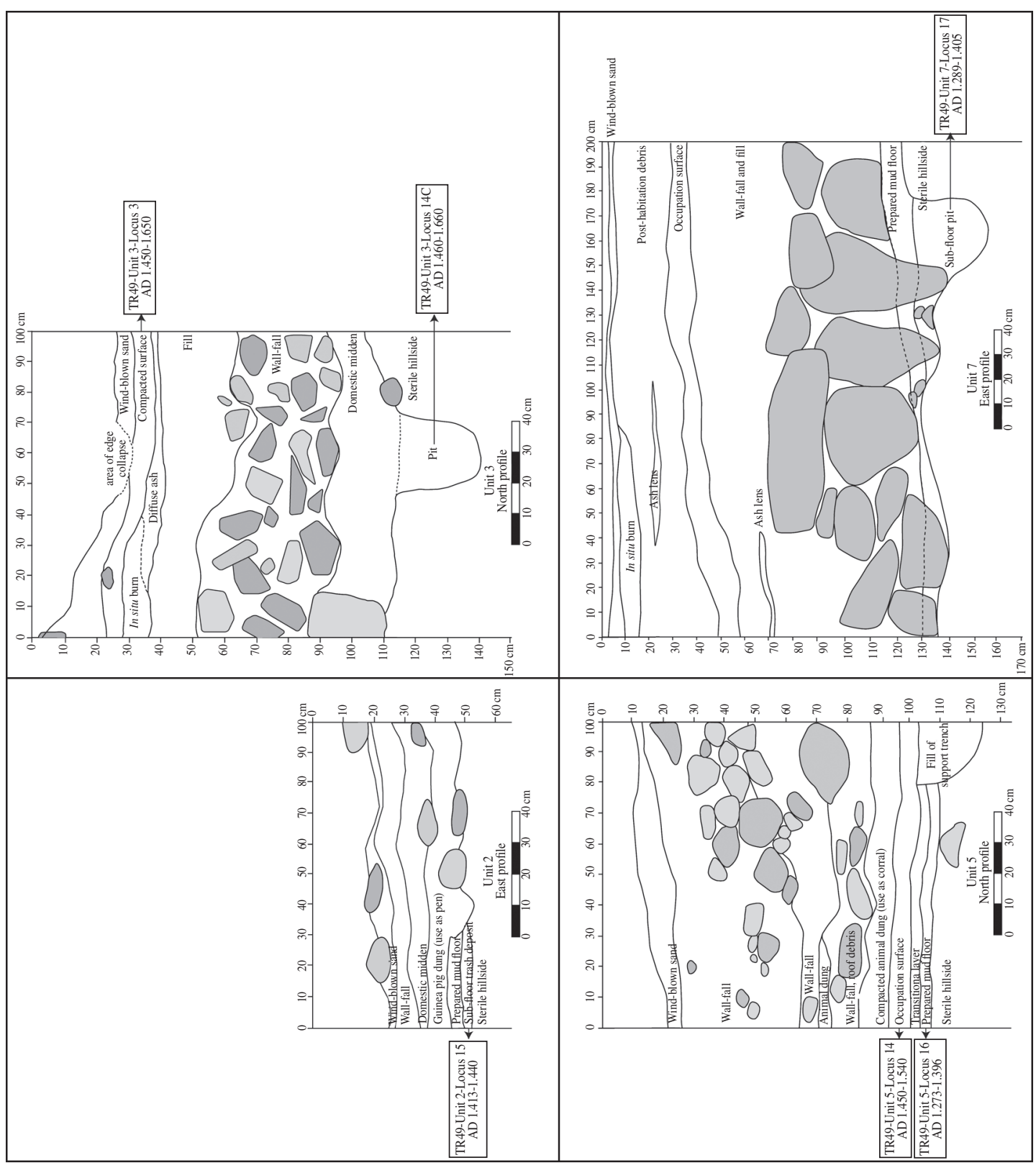

Figure 6. Vertical position of radiocarbon dates in the profiles of Units 2, 3, 5 and 7.

Perfiles estratigráficos de excavación en Tarapacá Viejo con posición vertical de fechados radiocarbónicos $14 C$ en Unidades 2 , 3,5 y 7 .

period. The wall, found in Unit 7, is either contemporary with or earlier than the prepared mud floor dated to 1,289-1,405 cal. AD that abuts the foundation stones (Figure 8). All ceramics recovered in the sub-floor deposits were in the Pica-Tarapacá Complex styles, supporting the interpretation that the floor, and wall with which it is associated, date to the pre-Inka period. Although the upper courses have collapsed, the foundation stones and two to three additional courses comprised large boulders, much greater in size than were observed in even the foundations of the Inka period walls in Units 3, 5, and 6 . These boulders were stacked together without using mortar; instead, small stones had been used to fill the gaps between the larger ones (Figure 9). The wall was constructed without the use of an 


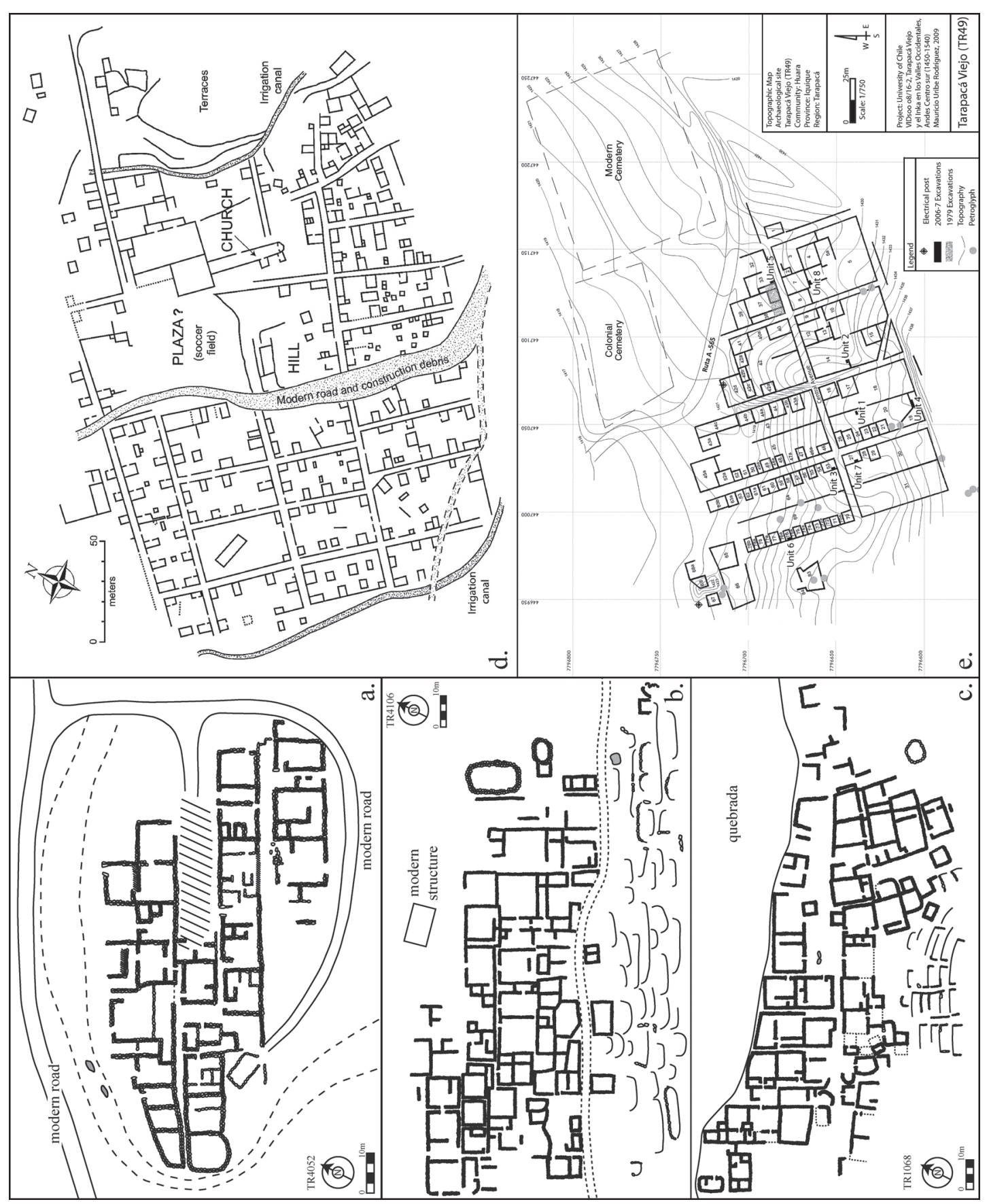

Figure 7. Comparison of the layouts of agglutinated Late Intermediate Period settlements in the Tarapacá Valley (7a, b, and c) and the planned Inka layout of Torata Alta in the Moquegua Valley (7d, courtesy of P. Rice) and Tarapacá Viejo (7e, modified from Uribe and Urbina 2010).

Comparación de la traza de asentamientos aglutinados del Periodo Intermedio Tardio de la quebrada de Tarapacá (7a, b, y c) y la traza planificada inkaica de Torata Alta en el Valle de Moquegua ( 7 d, cortesía de P. Rice) y Tarapacá Viejo (7e, modificado de Uribe and Urbina 2010). 


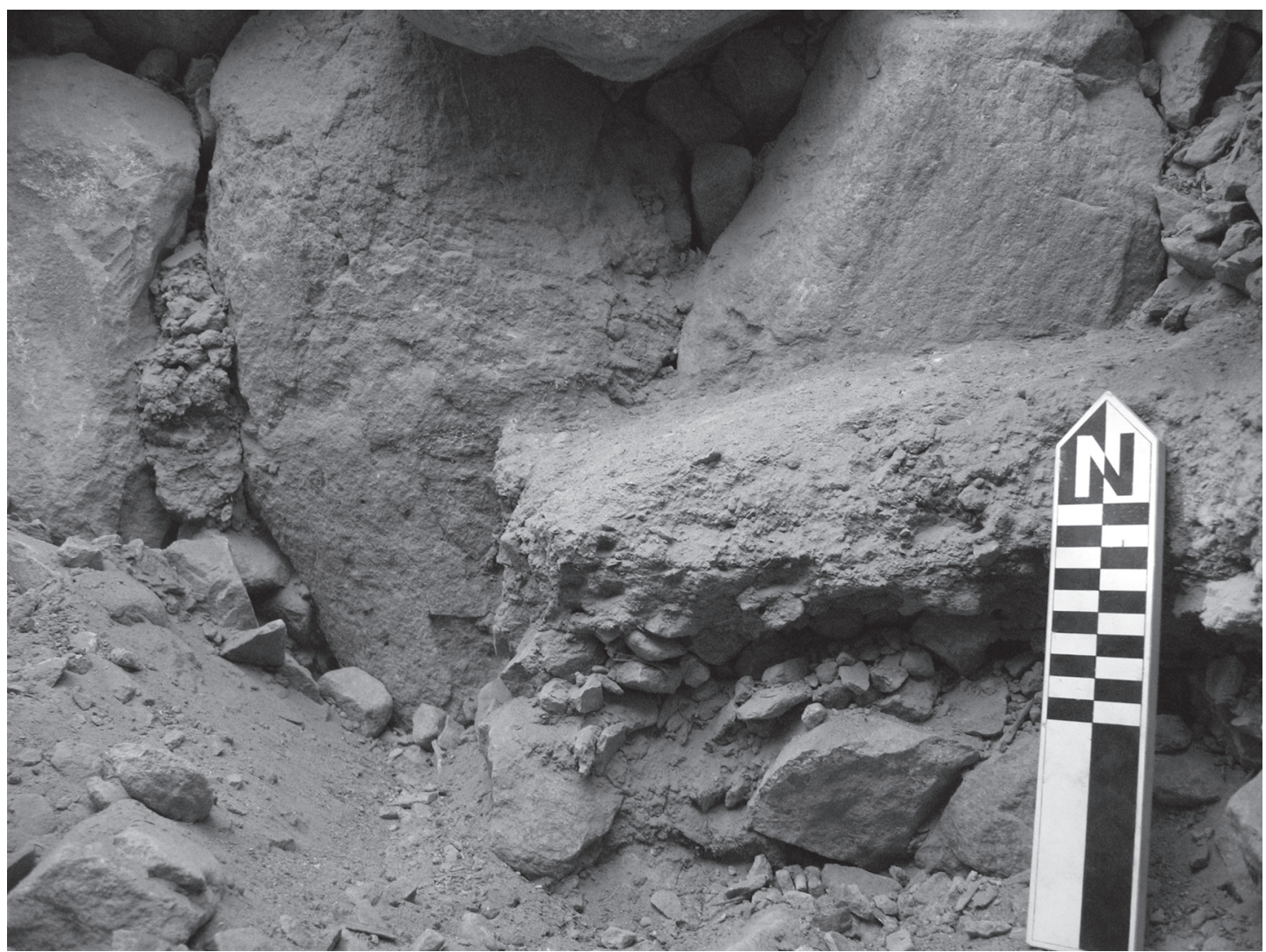

Figure 8. Floor lipping up against Late Intermediate period wall in Unit 7 (Tarapacá Viejo). Piso preparado adyacente al muro del período Intermedio Tardío en Unidad 7 (Tarapacá Viejo).

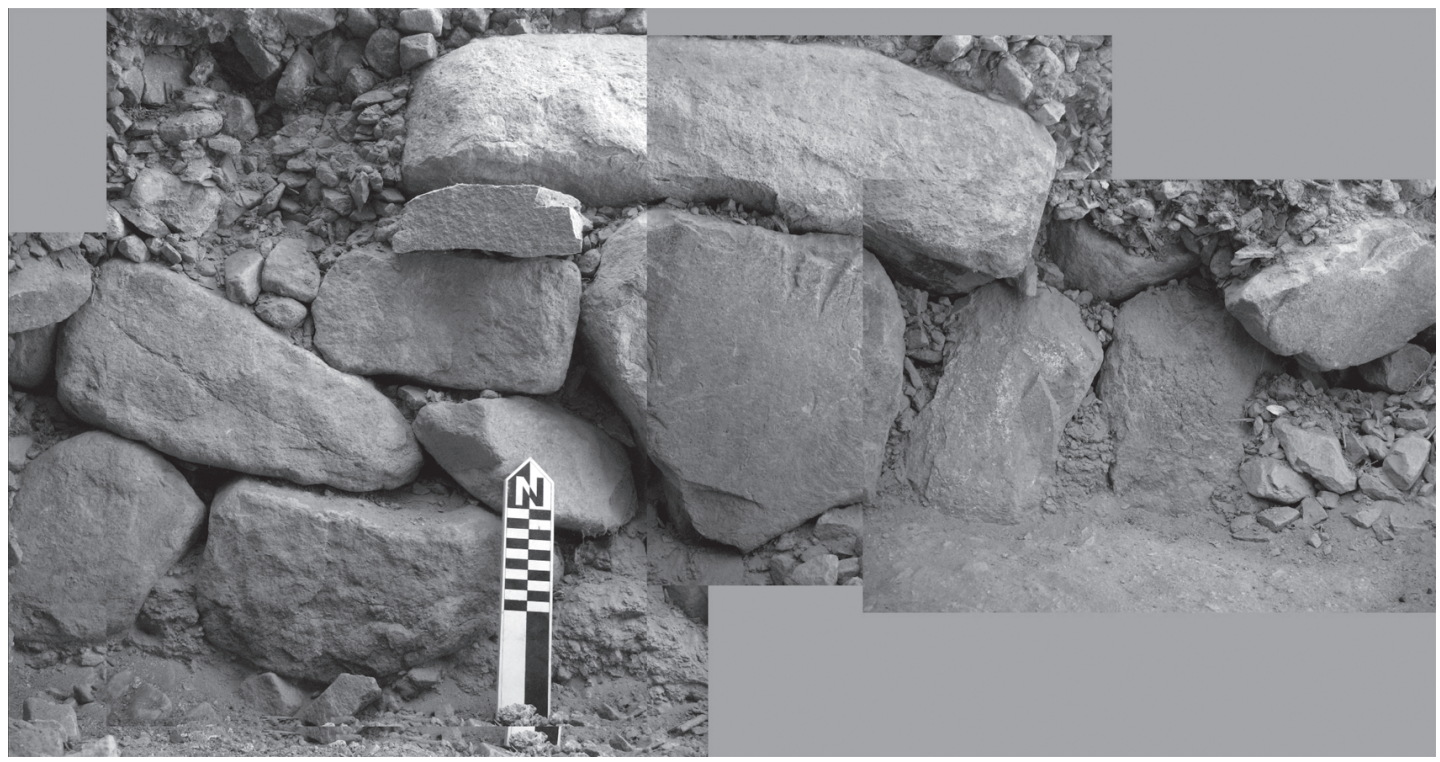

Figure 9. Composite image of Late Intermediate period wall in Unit 7 (Tarapacá Viejo).

Imagen compuesta de muro del período Intermedio Tardío en Unidad 7 (Tarapacá Viejo). 
architectural support trench. Prepared mud floors and the construction of walls using large boulders without mortar or architectural support trenches are features of the local architectural style in use before the conquest of the valley by the Inka.

\section{Architectural layout of Tarapacá Viejo}

The regular blocks and almost urban layout of Tarapacá Viejo (Figure 2) are unique among both prehistoric and historic period sites in northern Chile. Some scholars argue that the layout of Tarapacá Viejo was imposed by the Inka during the Late Horizon (AD 1,450-1,532; Núñez 1979; Urbina 2010; Uribe and Urbina 2010; Uribe et al. 2012), while others contend that the present organization of the site derives from Spanish influence and that the site functioned as a "pueblo de indios" after the arrival of European rule after AD 1,536 (P. Núñez 1984, 1992). Based on comparison with the layout of sites in the Tarapacá Valley and adjacent parts of the empire (Figure 7), as well as the construction characteristics of Inka-influenced sites in the other valleys of northern Chile, we suggest that the layout of Tarapacá Viejo was a product of Inka involvement and represents a fusion of the local architectural traditions of the Tarapacá Valley and influences drawn from the imperial heartland and other Inka sites in the south central Andes.

The architectural layout visible today at Tarapacá Viejo comprises eight rectangular compounds or blocks separated by perpendicular streets (Figure 2). An additional two or more blocks likely existed where the modern and historical cemeteries are now located. Although roughly similar in width across the site, the compounds in the northern alignment are somewhat longer (Table 3). A total of 108 rooms were identified in the 3 ha site (Adán and Urbina 2005). Most of the walls (75\%) were of double-wall-and-fill construction, while an additional $16.6 \%$ were of double walls without fill, both architectural styles associated with the Late Horizon in northern Chile (Adán and Urbina 2005; Urbina 2010). Many of the rooms were relatively large, with the majority falling between $20-40 \mathrm{~m}^{2}$ and above $60 \mathrm{~m}^{2}$, and there is a notable absence of structures smaller than $10 \mathrm{~m}^{2}$.

Internal architecture in the compounds of the eastern sector is relatively complex, with the interior spaces divided into rooms of unequal sizes. Walls dividing the compounds into halves are not continuous, and are in some cases absent. By contrast, the four compounds in the western sector of the site are divided completely along the long axis by a wall, and internal architecture is limited to small structures lining the exterior walls. The doorways of these rooms open onto the long, internal spaces of the compound, or onto narrow halls between the interior structures. Excavations in one of the large, open internal spaces indicates that they were the location of domestic activities, such as food processing and preparation, as well as craft production, including stone tool manufacture and copper metallurgy (Zori 2011). Use of the long internal spaces was probably shared by the various residents of the compounds. Each half of the two western-most compounds has a doorway linking the large open internal space with the site's primary east-west street, and the compounds have additional doors onto the perpendicular streets as well.

Absence of a plaza and a clearly defined location for a church, as well as the fact that structures within

Table 3. Dimensions and surface area of extant compounds at Tarapacá Viejo (from Adán and Urbina 2005: Cuadro 17). Dimensiones y superficie interna de canchas o complejos mayores en Tarapacá Viejo (en Adán and Urbina 2005: Cuadro 17).

\begin{tabular}{ccccc}
\hline Compound & Type & Length $(\mathrm{m})$ & Width $(\mathrm{m})$ & Surface Area $\left(\mathrm{m}^{2}\right)$ \\
\hline $30 / 31$ & RPC cancha & 50 & 36 & 1800 \\
$64 / 69$ & RPC cancha & 62 & 36 & 2232 \\
$18 / 20$ & RPC cancha & 50 & 37 & 1850 \\
$43 / 45$ & RPC cancha & 67 & 34 & 2278 \\
14 & Internally subdivided & 44 & 39 & 1716 \\
42 & Internally subdivided & Unknown* & 42 & Unknown* \\
3 & Internally subdivided & 51 & 39 & 1989 \\
34 & Internally subdivided & Unknown* & 36 & Unknown* \\
\hline
\end{tabular}

* Destruction of the site incurred in construction of the modern automobile road precludes the precise measurement of the compound lengths in the northern half of the site. 
the compounds open on to internal spaces rather than the site's streets (Cummins 2002), suggest that the site layout predates the Colonial period (Urbina 2010; Uribe and Urbina 2010; Zori 2011). That one of the main axes of the site is a section of the east-west Inka road further supports the notion that the settlement was Inka in design.

Based on their layout and probable Late Horizon date, the compounds in the western half of the site have been designated as "canchas" by Urbina (2010), although they clearly diverge from the traditional canchas of the Inka heartland and even some of the sites in northern Chile (e.g. Zapahuira and Inkaguano) discussed above. Instead, they assume some characteristics of the RPC (rectángulo perimetral compuesto) architectural layout considered a hallmark of Inka construction in the south central Andes (Raffino 1981; Raffino et al. 1985). As described by Hyslop (1984:282), RPC structures "are not exactly the same, but always express the idea of a rectangular (or nearly rectangular) wall surrounding one or a number of independent one-room rectangular structures. The placement of these structures within the enclosure is somewhat variable. They are always aligned with, and sometimes join, the enclosing wall". A manifestation of the Inka cancha tradition specific to the south central Andes, RPC architecture has been observed at numerous Inka sites in Argentina, Bolivia and northern Chile (Adán 1999; Adán and Urbina 2005; Barcena 1988; Hyslop 1984, 1990; Raffino 1981; Raffino et al. 1985; Uribe 2005).

At the same time, the overall layout of Tarapacá Viejo is quite clearly distinct from the other RPC settlements identified in the south central Andes, particularly in terms of the orderly repetitiveness and urban character of its streets and blocks. In this, Tarapacá Viejo is more similar to the orthogonal layouts of Inka imperial administrative centers located to the north and northeast of the Tarapacá Valley, including Torata Alta in the Moquegua Valley (Figure 7 for comparison with Tarapacá Viejo) and the sites of Hatuncolla and Chucuito in the Titicaca Basin (Hyslop 1990; Rice 2012; Stanish 2003).

As discussed above, many of the sites with Inka architecture in northern Chile contain two styles of architecture: rectilinear structures of Inka construction, and round structures using local building techniques that were inhabited by Inka subjects. This reflects a degree of continuity with the circular and often agglutinated and unplanned character of local pre-Inka site layouts, particularly in the Lluta and Azapa valleys (Chacama 2005; Muñoz and Chacama 2006). By contrast, pre-Inka habitation sites in the Tarapacá Valley are characterized by rectilinear layouts with well-defined avenues of circulation and the absence of a plaza (Figure 7; see also Adán and Urbina 2005; Núñez 1983; Urbina 2010; Zori 2011). These characteristics appear to have been carried over into the Late Horizon layout of Tarapacá Viejo.

We suggest that the layout of Tarapacá Viejo represents a fusion of the local architectural traditions of the Tarapacá Valley and influences drawn from the orthogonal site plans implemented in the imperial heartland and the RPC layouts of Inka sites elsewhere in the south central Andes. This may reflect the nature of the relationship between the empire and the local communities of the valley, with Tarapacá Viejo representing a form of "architectural diplomacy" or "conciliatory architecture" (Cornejo 1999; Mackey 2003, 2010) that was neither wholly local nor entirely imperial in character, but which combined elements of both.

\section{Inka construction techniques at Tarapacá Viejo}

Test excavations at Tarapacá Viejo indicate that the site underwent major architectural remodeling in the late prehispanic period. There is little indication that this was the result of violent destruction. The extant compounds follow the Late Intermediate period orientation of the site, at least in the case of the Late Intermediate period wall observed in Unit 7 , and there are no burn layers or incontrovertible evidence for intentional destruction of earlier walls. Wall-fall and architectural stones, some with mortar still adhering, are found in late prehistoric cultural fill in Units 1, 3, 5, 6, and 7. Given the degree of tectonic activity characterizing northern Chile, it is not inconceivable that the site may have been damaged in an earthquake and subsequently rebuilt using Inka construction techniques.

Architectural remodeling at Tarapacá Viejo in late prehistory followed Inka architectural canons found at other Late Horizon sites in northern Chile (Table 1). Walls identified in Units 3, 4, 5, and 6 were built using architectural support trenches excavated into sterile soil (Figure 10), a technique used by the Inka at Pampa Alto Ramírez and possibly Saguara. These trenches cut through the prepared mud floors 


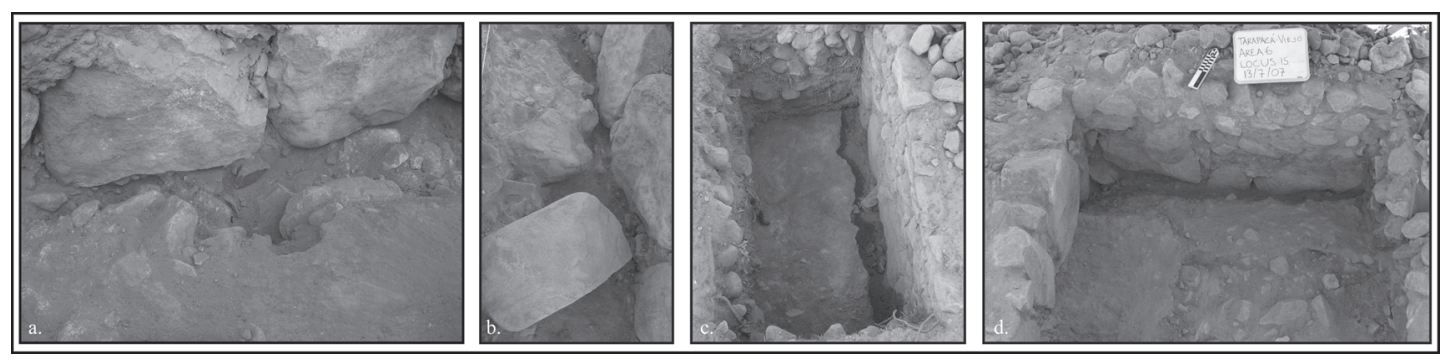

Figure 10a-d: Architectural support trenches identified in excavations of Unit 3 (10a), 4 (10b), 5 (10c), and 6 (10d) at Tarapacá Viejo. a-d: Trincheras o zanjas arquitectónicas de apoyo identificadas en excavación de Unidades 3 (10a), 4 (10b), 5 (10c) y 6 (10d) en Tarapacá Viejo.

dated to the Late Intermediate period, evidencing their later date (Zori 2011). Artifacts found in the fill of the trenches in Units 3, 4, 5, and 6 date exclusively to the Late Intermediate period and Late Horizon; Colonial period ceramics and other materials were absent from these trenches, again supporting a Late Horizon date for their construction and, by extension, the walls. The lowest or foundation courses of the walls in Units 3, 5, and 6 were comprised of larger boulders, and the upper courses of the walls were constructed of medium-sized stones selected and subsequently positioned to present flat exterior faces (Figure 10).

While local builders likely provided the labor, the close adherence to Inka construction methods observed at other sites throughout northern Chile suggests the integral participation of imperial representatives in the late prehistoric reconstruction of Tarapacá Viejo. Ethnohistoric sources document that the empire brought specialists into conquered communities to ensure that buildings were constructed according to Inka design. According to Cieza de León (1959 [1553], Ch. 19), "[t]he buildings at Tomebamba were erected by artisans who came from Cuzco and taught the others their craft". On the north coast of Peru, the empire left representatives to ensure that local populations reproduced imperial architectural forms: "[s]killed Indians remained with them to train them in what the Inca wanted them to know" (Cieza de León 1959 [1553], Ch. 113).

Alan Kolata (2013:144-5) has recently argued that Inka reliance on tribute in the form of labor service, rather than in commodities, had a profoundly transformative effect on subject populations. While the obligation to labor on the behalf or at the command of an imperial representative can also be seen as an externalized expression of political, economic, and social subordination, Kolata suggests that repeated collaboration in acts of labor service may "transform the consciousness of subject populations so that they perceive tributary obligations as a natural, constitutive element of their social relations with elites, both local and foreign" (Kolata 2013:145). The allocation of local labor and imperial supervision to the reconstruction of Tarapacá Viejo thus represents more than the alteration of the architectural spaces in which people lived and interacted, but also a step in the transformation of the historical consciousness of the Tarapacá Viejo community as they became more deeply enmeshed in the relationships constituting them as subjects in the Inka empire.

\section{Architectural Practices of the Colonial Period}

Tarapacá Viejo's transition from an Inka administrative center to a colonial town under Spanish rule entailed both changes and continuities in its architecture and layout. Modifications in roofing and wall construction techniques would have altered the appearances of the buildings at the site. Although the layout of the blocks and streets remained outwardly the same, the internal subdivision of compounds in the eastern half of the site attests to changes in the structure and function, and by extension, the organization of family life and domestic and craft production tasks. Nonetheless, the continued use of building techniques from earlier periods, such as architectural support trenches, testifies to the on-going presence of local peoples at Tarapacá Viejo and their role in re-making the site under a new imperial power.

\section{Post supports and roofing techniques}

During the Colonial period, the roofs of structures at Tarapacá Viejo were supported by large posts. 
This is indicated by the identification of two post holes, found in center of the rooms where Unit 6 and Unit 7 were located, respectively. The post holes are approximately $11 \mathrm{~cm}$ in diameter and surrounded by a circular area of compacted mud and gravel that served to anchor the post. Both are securely associated with floors dating to the Colonial period, in turn associated with walls that display characteristics typical of the Colonial period (see below). The beams themselves have been removed, probably when the site was abandoned (P. Núñez 1984:60).

Given the locations of the post holes, at the centers of the respective rooms where they were uncovered, it is likely that the beams supported roofs. The absence of post holes and roof support beams in the prehispanic contexts does not mean that the earlier structures were not roofed, only that the roofs did not require support posts. This would have been the case if they consisted of light mats laid flat across the tops of the walls, as is observed in some structures in the Tarapacá Valley today, or if the walls supported the beams of a pitched roof, as found at the site of Inkaguano. In fact, there is a long-standing tradition of the use of posts in prehistoric sites in the Tarapacá Valley, such as Caserones (see e.g. True 1980), although this practice does not appear in the pre-Colonial deposits at Tarapacá Viejo. Instead, the utilization of posts at Tarapacá Viejo is securely related to changes in roofing practices associated with the Colonial occupation at this site.

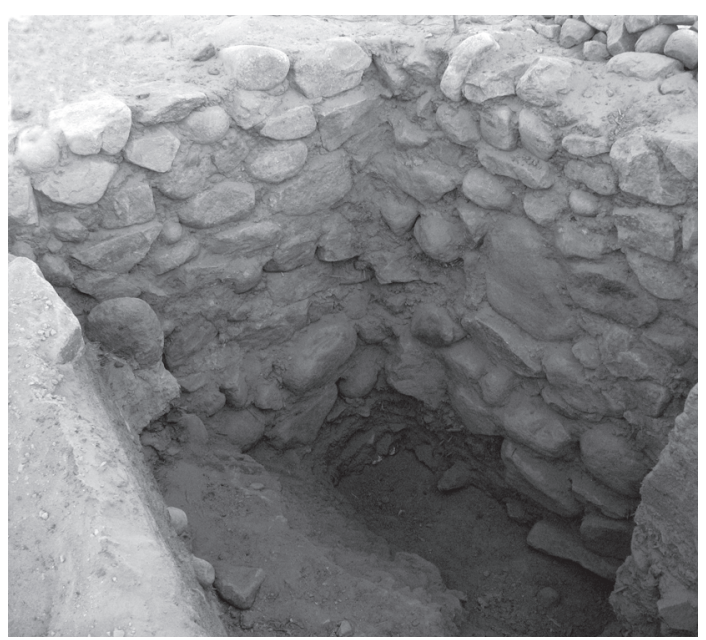

Figure 11. Colonial period architectural support trench from Unit 8. Trinchera o zanja arquitectónica de apoyo del período Colonial en Unidad 8.
Insight into Colonial roofing techniques comes from Unit 8 (Figure 2), where cane and other botanical material was found lashed to longer branches using vegetable fiber rope. This piece of roofing had been plastered on the exterior with compact, grayish clay. Similar roof construction has been observed at other Colonial structures in the valley. The roofs of these Colonial structures also differ from the prehistoric roofing proposed for Tarapacá Viejo in their form: they are pitched roofs that angle upwards to meet in the middle. Such a configuration would have required the support beams indicated by the post holes left behind. This novel style of roofing would have created new internal spaces within the rooms of Tarapacá Viejo, while at the same time altering the outward appearance of the structures to conform more closely to European aesthetic norms (e.g. Jamieson 2000).

\section{Architectural support trenches and changes in wall construction}

The use of architectural support trenches during the Colonial period at Tarapacá Viejo attests to the persistence of prehispanic building techniques among the local laborers likely responsible for construction there. Even the use of trenches, however, did not remain unchanged, and other technical aspects of Inka style wall construction were abandoned by the site's inhabitants.

Given the level of seismic activity in northern Chile, it is not surprising that builders at Tarapacá Viejo continued to use architectural support trenches in Colonial period constructions. As exemplified in Unit 8, however, the architectural support trenches of the historic period were less regular in shape and much wider, reaching almost a meter in width (Figure 11). By contrast, the architectural support trenches dating to the Inka period are of a consistent width and rarely extend more than $10-20 \mathrm{~cm}$ outside the foundation stones (Figure 10). The presence of iron nails and other hardware, glass, paper, and glazed ceramics in the support trench in Unit 8 clearly dates its construction to the Colonial period (Zori 2011).

Although of similar dimensions as walls revealed in Units 3 and 5, the Colonial-era wall in Unit 8 differs from earlier constructions at the site on two additional counts. First, the foundation stones are no larger than those of the upper courses (Figure 11). Second, the stones of the wall are not set flush 
against each other to create a flat internal surface, but instead protrude past the mortar uniting them. Other Colonial walls at the site display a high ratio of mortar to stone and rested on a layer of fill rather than a trench excavated into the sterile hillside. These features distinguish the Colonial period walls from those built under Inka supervision.

Overall, historical era walls are less uniform and standardized in their construction than those of the preceding period. This likely resulted from the absence of an overarching authority managing Colonial period construction at the site. Instead, wall construction during this time was undertaken by individuals drawing on a range of construction traditions-some local, some reflective of retained Inka influence, and others European.

\section{Changes in site layout during the Colonial Period}

Although the perimeter walls of the compounds at Tarapacá Viejo were left more or less unchanged, the compounds in the eastern portion of the site were internally subdivided during the Colonial period (Figure 2), relying on a very different logic underlying the organization of space. In contrast with the western compounds lined with small domestic structures opening onto common internal spaces used for craft production and other activities, the rooms in the eastern compounds of the site open onto each other and finally out to the street, with no clear shared public spaces.

This is typical of the organization of domestic space imposed under Colonial rule, in which the individual family houses constituting the city blocks were required to open onto the street. As discussed by Tom Cummins, this was part of an explicit Spanish policy designed to "inhibit sexual relations between close relatives that hitherto had been facilitated by the contiguous and connecting spaces of the [Inka] cancha... The single and public entrance of the new colonial house could be policed by public vigilance in order to create Spanish norms of the family and to instill 'decency"' (Cummins 2002:217). Albeit still residing within the confines of the earlier prehispanic compounds, inhabitants of the eastern blocks no longer shared a common space in which to engage in craft production or daily household activities. Focus was instead directed outward, onto the streets, where behavior of the residents could be observed and evaluated for its adherence to new social norms. These changes suggest a significant departure from how domestic life and production activities were structured during the Inka period, as local people adjusted to the new realities of the Colonial period.

Why the architecture of the eastern blocks of Tarapacá Viejo experienced a greater degree of modification is somewhat unclear. Evidence suggests that some architectural changes did occur in the western blocks-for instance, both examples of post holes/supports indicative of Colonial period roofing were found in the western blocks. One possibility is that the occupation of this portion of the site was less intensive, a suggestion supported by the relative scarcity of historic ceramics and artifacts. Nonetheless, a small quantity of faunal and botanical remains recovered in the western portion of the site, including bones from domesticated animals such as cattle (Bos taurus; Unit 3 and Unit 4) and sheep (Ovis sp.; Unit 4) and a handful of wheat grains (Unit 3), suggest that the western blocks remained in use by people adopting some parts of the Spanish cultural package while eschewing the remodeling of domestic layouts and the accompanying alterations to social interactions between residents.

\section{Discussion and Conclusions}

Architecturally, three distinct styles of construction at Tarapacá Viejo bear witness to the succession of cultural influences in the Tarapacá Valley through the late prehispanic period and into the historical era (Table 4). During the Late Intermediate period, investment in the construction of massive walls and prepared mud floors testifies to Tarapacá Viejo's role as a political and economic center, and is further manifest in the profusion of trade goods and ceramic styles found there. Trade connections maintained by the inhabitants of Tarapacá Viejo and the regional influence generated by these relationships may have influenced Inka selection of the site as the principle node of administration for the valley and surrounding region.

The formalization of the Inka road system in northern Chile perpetuated Tarapacá Viejo's preeminent status and connected it to other imperial nodes, such as Saguara, Hacienda Camarones, and Inkaguano, in every direction. As with other mid- to upper valleys in northern Chile, the Inka established an administrative presence at a pre-existing site with 


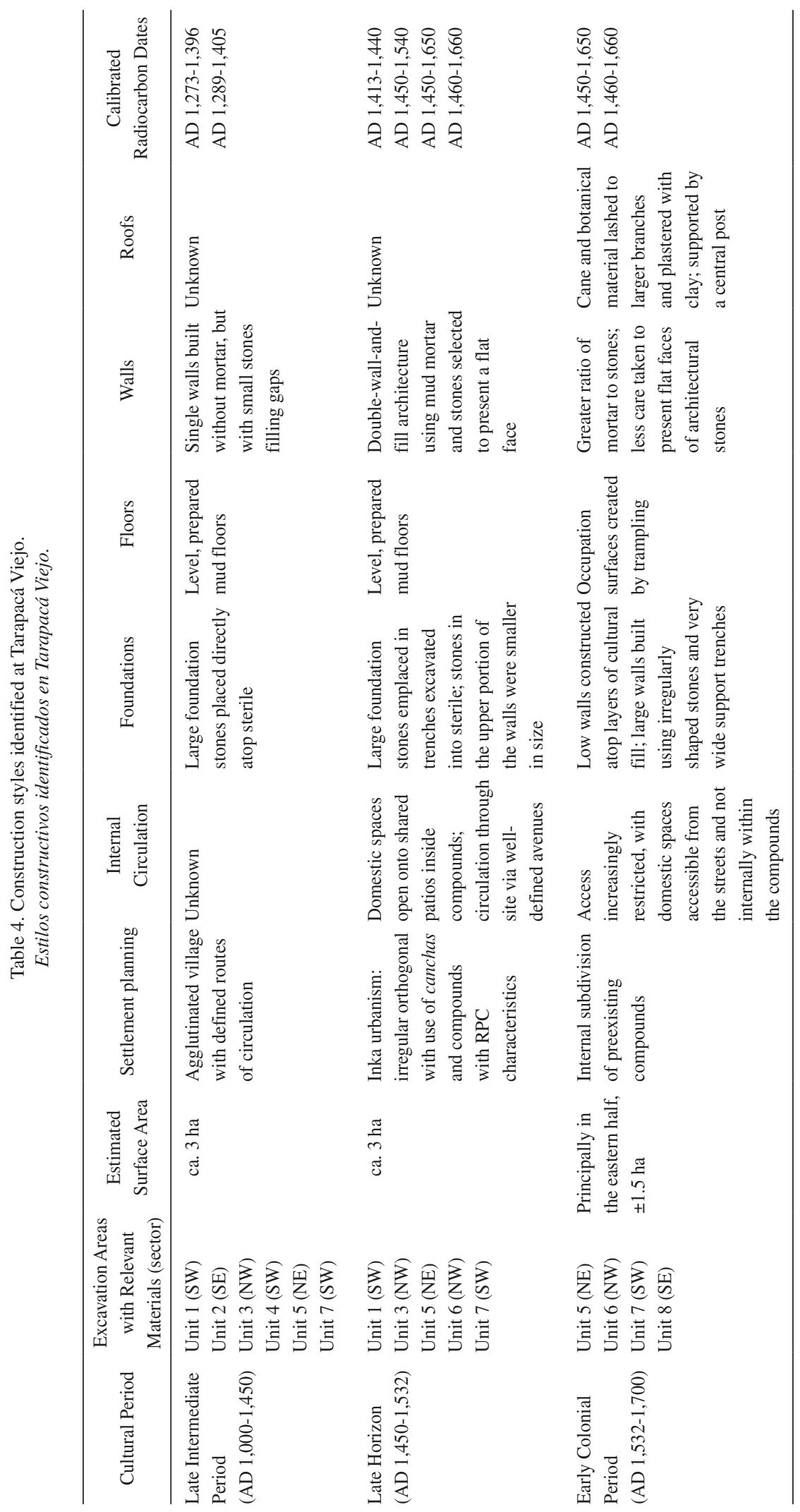


an important Late Intermediate period occupation. Tarapacá Viejo's relatively large population, as well as the presence of well-connected local leaders to liaise with imperial administrators, would have played a critical role in the imperial political economy in the region. Most likely carried out by Tarapacá elites recruited by the Inka, administrative activities on behalf of the empire focused on managing the labor needed for the extraction of silver-bearing ores from the Huantajaya mines; overseeing the skilled metallurgists at Tarapacá Viejo as they extracted and refined the silver; furnishing food, fuel, cloth, and other resources needed to support the individuals engaged in the metal production sequence; and the collection of the purified silver (Zori and Tropper 2010, 2013). Despite the fact that Tarapacá Viejo has no obvious Inka storage structures, as were observed at Zapahuira and Inkaguano, it is nonetheless probable that commensal hospitality and the provisioning of food and alcohol were a vital part of the Inka strategy for managing relations with the site residents.

Efforts on the part of the empire to secure the willing participation and cooperation of Tarapacá Viejo's inhabitants may also account for the unusual architectural layout of the site, which fuses elements of local Tarapacá Valley sites -such as rectilinear architecture, well-defined avenues of circulation, and absence of a plaza- with the irregular orthogonal layout of imperial Inka centers and the RPC compounds of the south central Andes (Hyslop 1990). Like the majority of the mid-valley and highland sites in northern Chile dating to the Late Horizon, one of the most conspicuous symbols of Inka power in the provinces -the ushnu- was absent at Tarapacá Viejo, supporting the assertion that imperial representatives were not interested in making overt statements about political domination (see also Mackey 2010:243-244). Construction methods used in remodeling the site, however, closely mirror those of other Inka sites in northern Chile, most notably in the use of double-wall-and-fill construction with mud mortar, architectural support trenches, foundation stones that are significantly larger than those of the upper courses, and the careful selection and positioning of building stones to present flat faces. Despite concessions in the layout, the adherence to imperial-style construction methods across the entirety of the site indicates a high degree of participation and oversight by Inka representatives in the reconstruction of Tarapacá Viejo. Particularly if cast within the idiom of reciprocity and indebtedness typical of the Inka, and the Andes more generally, collaboration in the reconstruction of Tarapacá Viejo in the new Inka style would have been an important step towards drawing local people into cycles of obligatory interactions with imperial representatives and towards redefining the site residents as participating members of the Inka political collective.

European influence led to additional changes in physical organization and construction techniques in some sectors of the site. While subterranean architectural support trenches continued to provide structural stability, changes in roofing techniques and the increased ratio of mortar to building stones would have altered the outward appearances of Colonial period buildings. Comparatively, historical era walls are less uniform and standardized than those of the late prehispanic period, suggesting that internal divisions of the compounds were the result of individual builders rather than constructions at the behest of an overarching authority managing construction. These internal divisions furthermore testify to changes in the spatial organization of domestic and productive spaces that resulted from the imposition of European social and religious norms. In particular, changes in access and circulation patterns resulting from these internal divisions would have reduced the use of shared internal spaces within the compounds and created a degree of spatial division between residents, with Tarapacá Viejo households carrying out daily food preparation and the small-scale production of crafts on an individual basis. This speaks to a fundamental difference in the interests and strategies of Inka versus Colonial powers. Whether secular or religious, Colonial leaders relied much less on reciprocity, accommodation, and integrative community-level interactions than had their Inka predecessors. Nonetheless, the continuity of prehistoric building practices into the Colonial period suggests that changes to the site layout were the product of native or mestizo residents in the process of assimilating and reproducing aspects of the European cultural package at Tarapacá Viejo. The architectural changes that accompanied the Colonial period can therefore not be seen as the result of a top-down phenomenon of European imposition.

Tarapacá Viejo was abandoned in ca. 1,717, possibly as a result of an epidemic (P. Núñez 1984), and the settlement was moved across the river to its present location. The standing walls of the site, 
however, remain a testament to the Inka and Spanish imperial strategies in northern Chile, as well as the local population and craftsmen who built, rebuilt, and inhabited this site across centuries of changing political allegiances.

Acknowledgements: These investigations were conducted under the Tarapacá Valley Archaeological Project, Project FONDECYT 1030923, and Project VID SOC08/16-2. Financial support was provided by the National Science Foundation; the Cotsen Institute of Archaeology; the Department of Anthropology at UCLA; the Chilean National Fund to Support Science and Technology (Fondo Nacional de Apoyo a la Ciencia y Tecnología (FONDECYT); and the Vice-Rectory for Investigation and Development at the University of Chile. The second author is granted a scholarship by CONICYT. Our sincerest gratitude to Mauricio Uribe, Ran Boytner and the students of UCLA and the Universidad de Chile for their help, as well as to Davide Zori, Erika Brant, Leonor Adán, Jorge Hidalgo, Estefanía Vidal and two anonymous reviewers for comments on earlier versions of this paper.

\section{References Cited}

Adán A., L. 1999. Aquellos antiguos edificios. Acercamiento arqueológico a la arquitectura prehispánica tardía de Caspana. Estudios Atacameños 18:13-33

Adán, L. and S. Urbina 2005. Arquitectura, asentamiento y organización social en las quebradas tarapaqueñas durante los periodos tardíos: análisis arquitectónico de los sitios Camina-1, Laymisiña, Carora, Tarapacá Viejo, Caserones-1 y Jamajuga. Interim report for Proyecto Fondecyt 1030923.

Advis, P. 2008. El Desierto Conmovido. Paso de la Hueste de Almagro por el Norte de Chile. Dirección de Extensión Académica y Cultural, Universidad Arturo Prat, Iquique.

Barcena, J.R. 1988. Investigación de la dominación incaica en Mendoza. El tambo de Tambillos, la vialidad anexa y los altos cerros cercanos. Espacio, Tiempo, y Forma, Serie 1, Prehistoria 1:397-426.

Berenguer, J. 2009. Chile bajo el Imperio de los Inkas. Museo Chileno de Arte Precolombino, Santiago.

Berenguer, J., C. Sanhueza and I. Cáceres 2011. Diagonales incaicas, interacción interregional y dominación en el altiplano de Tarapacá, norte de Chile. In En Ruta, Arqueología, Historia y Etnografía del Tráfico Sur Andino, edited by L. Núñez and A. Nielsen, pp. 247-283. Encuentro Grupo Editor, Córdoba.

Bollaert, W. 1851. Observations on the geography of Southern Peru, including survey of the Province of Tarapaca, and route to Chile by the Coast of the Desert of Atacama. Journal of the Royal Geographical Society of London 21:99-130.

Briones, L., L. Núñez and V. Standen 2005. Geoglifos y tráfico prehispánico de caravanas de llamas en el desierto de Atacama (norte de Chile). Chungara Revista de Antropología Chilena 37:195-223.

Bronk Ramsey, C. 2009. Bayesian analysis of radiocarbon dates. Radiocarbon 51:337-360.

Chacama, J. 2005. Patrón de asentamiento y uso del espacio. Precordillera de Arica, extremo norte de Chile, siglos X-XV. Bulletin de l'Institut Français d'Etudes Andines 34:357-378.

Cieza de León, P. 1959 [1553]. The Incas of Pedro de Cieza de León. Translated by H. De Onis. University of Oklahoma Press, Norman.
Cobo, B. 1979 [1653]. History of the Inca Empire: An Account of the Indians' Customs and their Origin, Together with a Treatise on Inca Legends, History, and Social Institutions. Translated by R. Hamilton. University of Texas Press, Austin.

Cornejo B., L. 1999. Los Incas y la construcción del espacio en Turi. Estudios Atacameños 18:165-177.

Cummins, T. 2002. Forms of Andean Colonial Towns, Free Will, and Marriage. In The Archaeology of Colonialism, edited by C. Lyons and J. Papadopoulos, pp. 199-240. The Getty Research Institute, Los Angeles.

Cúneo-Vidal, R. 1977. Historia de los antiguos cacicazgos hereditarios del Sur del Perú. In Obras Completas, edited by I. Prado Pastor, Tomo I, Vol. 2, pp. 297-486, Lima.

deFrance, S. 1996. Iberian foodways in the Moquegua and Torata valleys of southern Peru. Historical Archaeology 30:20-48.

Dillehay, T. and L. Núñez 1988. Camelids, caravans, and complex societies in the South-Central Andes. In Recent Studies in Pre-Columbian Archaeology, edited by N.J. Saunders and O. De Montmollin, pp. 603-634. BAR International Series (421, Part II). Archaeopress, Oxford.

Gallardo, F., M. Uribe and P. Ayala 1995. Arquitectura Inka y poder in el pukara de Turi, norte de Chile. Gaceta Arqueología Andina 24:151-171.

Gasparini, G. and L. Margolies 1980. Inca Architecture. Indiana University Press, Bloomington.

Hidalgo, J. 2009. Civilización y fomento: la 'Descripción de Tarapacá' de Antonio O'Brien, 1765. Chungara Revista de Antropología Chilena 41:5-44.

Hyslop, J. 1984. The Inka Road System. Academic Press, Inc., New York.

- - - 1990. Inka Settlement Planning. University of Texas Press, Austin.

Jamieson, R. 2000. Domestic Architecture and Power: The Historical Architecture of Colonial Ecuador. Kluwer Academic Publishers, New York.

Kolata, A. 2013. Ancient Inca. Cambridge University Press, New York. 
Mackey, C. 2003. La transformación socioeconómica de Farfán bajo el gobierno Inka. Boletín de Arqueología PUCP 7:321-353.

- - - 2010. The Socioeconomic and ideological transformation of Farfán under Inka rule. In Distant Provinces in the Inka Empire: Toward a Deeper Understanding of Inka Imperialism, edited by M. Malpass and S. Alconini, pp. 221-259. University of Utah Press, Iowa City.

Muñoz, I. and J. Chacama 2006. Complejidad Social en las Alturas de Arica: Territorio, Etnicidad y Vinculación con el Estado Inca. Ediciones Universidad de Tarapacá, Arica.

Muñoz, I., J. Chacama, G. Espinoza and L. Briones 1987. La ocupación prehispánica tardía en Zapahuira y su vinculación y la organización social y económica Inca. Chungara Revista de Antropología Chilena 18:67-89.

Niemeyer, H. and V. Schiappacasse 1988. Patrones de asentamiento incaico en el Norte Grande de Chile. In La frontera del Estado Inca, edited by T. Dillehay and P. Netherly, pp. 141-179. BAR International Series. Archaeopress, Oxford.

Núñez, L. 1979. Emergencia y desintegración de la sociedad tarapaqueña: riqueza y pobreza en una quebrada del norte chileno. Atenea 439:163-213.

- - - 1984. Tráfico de complementariedad de recursos entre las tierras altas y el Pacífico en el área Centro Sur Andina. Unpublished Ph.D. thesis, University of Tokyo, Tokyo.

Núñez, P. 1983. Aldeas tarapaqueñas. Notas y comentarios. Chungara 10:29-37.

- - - 1984. La antigua aldea de San Lorenzo de Tarapacá, norte de Chile. Chungara 13:53-65.

_ _ - 1992. Tarapacá Viejo: Es el pueblo de indios de Lucas Martínez Vegazo? In Comunidades Indígenas y su Entorno, edited by M.O. Muermann and J.G. Muñoz, pp. 59-66. Universidad de Santiago de Chile, Santiago.

Piazza, F.K. 1981. Análisis descriptivo de una aldea incaica en el sector de Pampa Alto Ramírez. Chungara 7:172-210.

Pizarro, P. 1986 [1571]. Relación del Descubrimiento y Conquista de los Reinos del Perú. Pontificia Universidad Católica del Perú, Lima.

Raffino, R. 1981. Los Inkas del Kollasuyu. Ramas Americana Editora, Buenos Aires.

Raffino, R., R. Alvis, L. Baldini, D. Olivera and M.G. Rivina 1985. Hualfin - El Shingal - Watungasta: Tres Casos de Urbanización Inka en el N.O. Argentino. Actas del IX Congreso Nacional de Arqueología, pp. 470-497. Sociedad Chilena de Arqueología/ Museo Arqueológico de la Serena, La Serena.

Rice, P. 2012. Torata Alta: An Inka Administrative Center and Spanish Colonial Reducción in Moquegua, Peru. Latin American Antiquity 23:3-28.

Sanhueza, C. 2008. Territorios, prácticas rituales y demarcación del espacio en Tarapacá en el siglo XVI. Boletín del Museo Chileno de Arte Precolombino 13:57-75.

Santoro, C. and I. Muñoz 1981. Patrón habitacional incaico en el área de Pampa Alto Ramírez (Arica, Chile). Chungara 7:144-171.

Santoro, C., A.L. Romero, V. Standen and A. Torres 2004. Continuidad y cambio en las comunidades locales, periodos Intermedio Tardío y Tardío, valles occidentales del área Centro Sur Andina. Chungara Revista de Antropología Chilena 36:235-247.
Santoro, C., V. Williams, D. Valenzuela, A. Romero and V. Standen 2010. An archaeological perspective on the Inka provincial administration of the South-Central Andes. In Distant Provinces in the Inka Empire: Toward a Deeper Understanding of Inka Imperialism, edited by M. Malpass and S. Alconini, pp. 54-74. University of Utah Press, Salt Lake City.

Schiappacasse, V. and H. Niemeyer 2002. Ceremonial Inca provincial: El asentamiento de Saguara (Cuenca de Camarones). Chungara Revista de Antropología Chilena 34:53-84.

Shimada, I. and M. Shimada 1985. Prehistoric llama breeding and herding on the north Coast of Peru. American Antiquity 50:3-26.

Stanish, C. 2003. Ancient Titicaca: The Evolution of Complex Societies in Southern Peru and Northern Bolivia. University of California Press, Los Angeles.

Trelles, E. 1991. Lucas Martínez de Vegazo: Funcionamiento de una Encomienda Peruana Inicial. Pontificia Universidad Católica del Perú, Lima.

True, D.L. 1980. Archaeological investigations in northern Chile: Caserones. In Prehistoric Trails of Atacama: Archaeology of Northern Chile, edited by C. Meighan and D.L. True, pp. 139-178. Institute of Archaeology, University of California, Los Angeles.

Urbina, S. 2009. El Altiplano de Tarapacá en Tiempos del Tawantinsuyo: Arquitectura de las Instalaciones Incaicas (S. XV-XI d.C). Tesis a optar al título profesional de Arqueólogo, Universidad de Chile, Santiago.

- - - 2010. Sobre espacialidad Incaica y planificación Hispana: Hacia una arqueología Colonial de Tarapacá, Siglos XV-XVII DC (norte de Chile). Actas del VI Congreso Chileno de Antropología, Volumen II, pp. 1992-2008. Colegio de Antropólogos de Chile, Santiago.

Uribe, M. 2006. Acerca de complejidad, desigualdad social y el complejo cultural Pica-Tarapacá en los Andes Centro-Sur (1000-1450 DC). Estudios Atacameños 31:91-114.

Uribe, M. and L. Adán 2004. Acerca del dominio inca, sin miedo, sin vergüenza. Chungara Revista de Antropología Chilena volumen especial 1:467-480.

Uribe, M., L. Sanhueza and F. Bahomondes 2007. La cerámica prehispánica tardía de Tarapacá, sus valles interiores y costa desértica, norte de Chile (ca. 900-1450 D.C.): una propuesta tipológica y cronológica. Chungara Revista de Antropología Chilena 39:143-170.

Uribe, M. and S. Urbina 2010. Tarapacá Viejo: Historia ocupacional de un centro incaico en los Valles Occidentales del norte de Chile. Actas del XVII Congreso Nacional de Arqueología Argentina, Volume III, pp. 1321-1326. Congreso Nacional de Arqueología Argentina, Mendoza.

Uribe, M., S. Urbina and C. Zori 2012. La presencia del inca y la incorporación de Tarapacá al Tawantinsuyu (Norte Grande de Chile). Actas del XVIII Congreso Nacional de Arqueología Chilena, pp. 217-228. Colegio de Antropólogos de Chile, Santiago.

Zori, C. 2011. Metals for the Inka: Craft Production and Empire in the Tarapacá Valley, Northern Chile. Ph.D. thesis, University of California, Los Angeles.

Zori, C. and P. Tropper 2010. Late Prehispanic and Early Colonial silver production in the Tarapacá Valley, northern Chile. Boletín del Museo Chileno de Arte Precolombino 15:65-87.

- - - 2013. Silver lining: evidence for Inka silver refining in northern Chile. Journal of Archaeological Science 40:3282-3292. 